\title{
The Consequences of Gender in Homogamic Couples
}

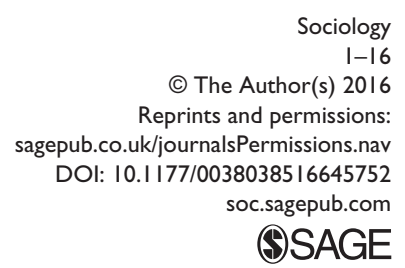

@SAGE

\section{Rodrigo Rosa}

University of Lisbon, Portugal

\begin{abstract}
In studies which analyse the social distance between spouses at the moment a couple is formed, and which attempt to understand the role of the family, and in particular of marriage, in crystallising social divisions, the concept of homogamy has often been purely descriptive. This article questions this static approach and seeks to pinpoint the changes which social homogamy undergoes in the course of conjugal life, addressing women's decisions on work-family articulation. Drawing on a critical approach to the concept of rational choice, the article intends to demonstrate the merit of an interpretative approach by analysing how members of a sample of 27 university-educated Portuguese partnered mothers take their decisions in the context of an interdependency framework in which the dynamics of family interaction tend to thwart individual career path development, rendering spouses dependent on each other.
\end{abstract}

\section{Keywords}

dual-earner couples, gender, homogamy, work-life balance

\section{Introduction}

Homogamy has been widely studied through the analysis of social inequality within the couple. There are not, however, many critical approaches of the concept of homogamy and, in particular, theoretical propositions for addressing the processes which affect the social distance between spouses over the course of their conjugal life (Singly, 1997 [1987]). Mate selection is often envisaged as the prime moment for observing homogamy, which is considered a key indicator of the role of the family in crystallising social inequality. However, this approach is based on the assumption that structural properties and resources are shared between spouses within a process of spontaneous osmosis.

\footnotetext{
Corresponding author:

Rodrigo Rosa, Instituto de Ciências Sociais. Av. Professor Aníbal de Bettencourt, 9 1600-I89 Lisboa, Portugal.

Email: rodrigo.rosa@ics.ul.pt
} 
Hence, instead of a descriptive analysis of the spouses' resources or social position at the onset of conjugal life, I suggest a dynamic approach to social homogamy. The aim of this article is therefore to demonstrate - through two work-life biographies - that social distance between spouses is subjected to change over the course of conjugal life as a result of the processes involved in combining work and family life.

With the decline of the male breadwinner model, combining work and family life has come to pose increasing challenges to conjugal negotiation. Instead of the dissolution of gender inequalities through the negotiation of family roles, there is an increasing complexity in the ways the gendered division of labour takes place within the family (Crompton, 2006). This article seeks to explain the mechanisms of inequality underlying work-family articulation by analysing the relational conditions under which women find solutions for overcoming the pressures of their job demands and family roles. Based on an interpretative framework, these solutions are conceptualised as strategies for reconciling family and work. I do not define female decisions simply as the outcome of rational choices and individual objectives, given that they cannot be dissociated from the gender norms, nor from the constraints of the gender division of labour observed in the job market, nor finally from the collective and interpersonal expectations which are part of the shared experience with their partners. In my view, female strategies for reconciling family and work reveal tensions which express the potential contradictions between self, career-related interests, social expectations regarding performance of family roles and perceptions of the effects of male dominance on individual autonomy.

My approach is grounded in a critique of both the heuristic limitations of the Bourdieuian perspective and more rationalist or subjectivist interpretations of the notion of strategy. The challenge here is to explore with two empirical examples women's ability to distance themselves from gender norms, as well as the implications of family relations of interdependence in their choices regarding work and family life. I believe individual choices to be closely connected with conjugal interaction. Assuming that the dynamics of conjugal interaction - defined here mainly as a system of influences (NicoleDrancourt, 1989) - determine how capital or resources are mobilised and necessarily affect individual career development trajectories, I distance myself from approaches which reduce family life to a system of exchanges between actors. Finally, I seek to emphasise the theoretical and analytical relevance of my approach to the study of homogamy, as well as its contribution to a broader debate on the relationship between action and structure.

\section{The Limitations of the Concept of Homogamy}

A number of research projects devoted to the study of mate selection have shown how crucial is the role of the family in crystallising socio-economic divisions in society (Bozon and Héran, 2006; Girard, 1981 [1964]; Rosa, 2005). The empirical evidence of the prevalence of homogamic patterns reveals the persistence of structural factors in mate selection. Educational and socio-occupational proximity between spouses at the moment a couple is formed is undoubtedly an indicator of the role family plays in reproducing social divisions. But this conceptualisation of homogamy is ill-suited to a deeper study of the relationship between conjugal life and social inequality for two main reasons. 
The first is its descriptive and static nature. This conceptualisation provides a summary social characterisation of the spouses at the moment a couple is formed and hence a snapshot of one stage of family life. It does not account for the paths both partners followed in occupational structure, which is marked by unequal opportunities according to gender. The second reason why this conceptualisation is ill-suited to a deeper study of the relationship between conjugal life and social inequality has to do with its gender-neutral nature. Homogamic marriage is therefore supposed to contribute to reproducing social inequality without the interference of gender mechanisms which do, however, shape the division of labour within the family. Hence this conceptualisation of the social distance between spouses is insufficient when it comes to observing how family life contributes to social inequalities between men and women. Rather than sticking to factors which broaden or narrow the social distance between spouses at the moment a couple is formed, this article looks at the evolving social distance between women and their partners. In selecting conjugal life as the object of study, my aim is to address the relationship between family, gender and social inequality.

\section{Dual Earners, Conjugal Life and Inequality}

Research on the relationship between family and social inequality in societies characterised by the predominance of the dual-earner pattern cannot be circumscribed to the analysis of the choice of spouse as a family strategy for social reproduction. It must cover the broader aspects of the effect of conjugal life on social inequalities between men and women. Over the course of conjugal life, the likely changes in social proximity associated with occupational mobility, which take the form of asymmetries in economic, educational and symbolic resources, are the by-product of gender mechanisms underlying the play of pre-given family roles or the negotiation of domestic work.

Evidence of the existence of social expectations of family roles to be performed in line with gender norms is the fact that it is women - even in societies where they are strongly represented in the labour market - who mainly play the role of caregivers, while men are able to follow their more hedonistic and spontaneous dispositions, because the domestic management work carried out by women provides them with the necessary support to do so (Delphy and Leonard, 1992). In most Portuguese households women still carry out the routine tasks, and this pre-given division of labour pattern has, objectively, resulted in substantial overload for working mothers (Wall and Guerreiro, 2005). Full-time dual-earner couples are the predominant model, as a result of the growing numbers of women working full-time since the 1974 Revolution, and it is highly qualified working mothers who are least likely to stop working during the different family transitions. ${ }^{1}$ Today more than 60 per cent of children in Portuguese couple families are in full-time dual-earner families (OECD, 2014). Family policies have had an effect on the prevalence of full-time employment of mothers with small children. In fact, the leave policy model is based on an early return to full-time work (Moss and Wall, 2007). In turn, social expectations of gender role performance lead to a frequent lack, in employers' policies and practices, of explicit arrangements reflecting the principles of gender equality (Guerreiro and Pereira, 2007).

The decline of the male breadwinner model and women's increasing labour market participation bring with it challenges to work-life balance (Crompton, 2006). Having a 
full-time job, and particularly a highly qualified job which is demanding in terms of qualifications, commitment and responsibility, reinforces women's propensity to develop strong career aspirations and thus involves changes in their relationship with the family (Rosa, 2013). In axiological terms, it exposes women to the possibility of self-realisation as subjects, and not merely as alienated members of a family institution. The career path of each member of the couple is thereafter exposed to differing criteria which cut across the very idea of 'individual maximisation', but are not necessarily grounded in economic rational choice (Becker, 1981). First, choices in how to combine work and family life are made on the basis of the opportunities a given individual may have in a general framework of constraints. Second, choices are made according to the behaviour of others, and according to the interplay between them and the position each one adopts in it. Lastly, choices are not the simple outcome of individual objectives, since they are subject to 'gendered moral rationalities', that is, to rational frameworks where notions of mothering/fathering are strongly linked to understandings about the proper way to combine work and family life (Duncan et al., 2003).

It is precisely because conjugal dynamics are organised above all according to the distribution of power between the spouses, including the 'normative power' (McNay, 1992) of social expectations embedded in gendered roles in the family, that we should avoid reducing conjugal interaction to a system of exchanges between individuals whose choices are only governed by their interests or 'preferences' (Hakim, 2000). As this article empirically observes, gendered cultural norms interfere with the balance of power between partners. The family is not the same as an economic system, but is rather a system of influences that is structured by gender and in which the dynamics of interaction tend to thwart the autonomy of the individual career path development for each partner, rendering them dependent on each other.

\section{An Interpretative Framework}

Instead of focusing on the moment a couple is formed, I suggest an approach which will show homogamy to be a process which is inevitably affected by conjugal life. My approach to homogamy here is dynamic, since I intend to explore the processes behind social distance or proximity over the course of marital life. I therefore address the processes of work-family articulation, and particularly analyse the solutions women find for reconciling family and work, as well as the relational circumstances in which those solutions are worked out. Underlying my approach, which is anchored in an analytical interpretative framework, is a conceptualisation of those female solutions as strategies for reconciling family and work. Two points relating to this concept require explanation.

First, I choose the term 'reconciling' because I am referring to a desirable objective behind each female strategy. Otherwise, when I look to how women actually combine work and family life I use the term 'articulation' instead of 'reconciliation'. The expression 'reconciliation of work and family', originally formulated as a desirable objective in the domain of family policy, has commonly made the transition to the academic debate without proper reflection on its inherent ideological content. Disregarding the structural constraints deriving from gender difference, the notion of 'reconciliation' is based on the normative assumption that it is for women to deal with the challenges of combining work 
and family life. Reconciliation between work and family life thus implicitly refers to reconciling female roles (Junter-Loiseau, 1999; Silvera et al., 2004). The idea of 'articulation', on the other hand, is better suited to a structural approach which emphasises the implications of gender social relations for actors' choices (Buffier-Morel, 2007). Moreover, the use of the notion of 'reconciliation' is not appropriate for an analytical approach to work and family arrangements, because it represents a normative pronouncement which does not envisage the possibility of conflict between work and family life (Le Bihan-Youinou and Martin, 2008; Wall, 2007).

Second, I should explain the idea of 'strategy'. I claim that female solutions for combining work and family life are not merely logical projections or rational decisions taken in line with individual objectives, nor are they unrelated to moral notions of 'the right thing to do' (Finch and Mason, 1993) and to gender norms which govern the division of labour in the job market. Female solutions for combining work and family life therefore require an understanding of the notion of strategy not as a 'product of a conscious objective', but as being synonymous with a 'practical sense' which, according to Bourdieu (1987) is the result of the activation of incorporated dispositions. I do not, however, adopt the strictly Bourdieuian notion of strategy, because I assume there are a variety of complex interacting mechanisms involved in action which are dissociated from and are therefore in contrast to those in the strongly integrated societies studied by Bourdieu (1972). This is particularly true for the solutions women adopt for combining work and family life.

My argument is close to the critique of the concept of habitus undertaken by both Mouzelis (2000) and Dubet (1994). The former rejects the concept's inability to incorporate rational choice and the making of 'tactical plans' in the process of interaction, since this leads to an over-estimation of the unconscious or automatic nature of actors' strategies, which are consequently confined within family strategies. The latter sees in the notion of habitus the assumption that individual interests and collective interests - in this case family interests - necessarily coincide in action. Looking at the concept as a whole, we may draw the conclusion that these differing dynamics are two sides of the same coin, and this is true for societies in which family and economy are more closely tied. But this point of view is not appropriate in a societal context in which there is a mismatch between market mechanisms and social inclusion, and particularly between individual careerrelated interests and social expectations regarding performance of family roles. As Dubet (1994) claims, the different dynamics - 'inclusion, strategic action and subjectivation' - behind individuals' actions no longer match established norms and roles, and they are in a continuing state of tension which individuals are forced to manage.

Thus, in order correctly to interpret the management of such dynamics involved in choices relating to work-family articulation, it is important to look into the relevant situations and processes of which those choices are a part. I argue therefore that it is only possible to give meaning to the solutions women adopted to combine work and family - in other words, to understand them as strategies - if we relate them to the contexts of interdependence within which they are forged. There are two fundamental reasons why such choices cannot effectively be disconnected from family relations of interdependence. First, the relations of interdependence in which decisions on work-family articulation are taken derive from the inter-subjective dynamics. By way of example, a partner's 
lack of recognition of the constraints of his or her profession, as well as conflicting notions about the right thing to do, interfere with such dynamics. Second, family relations of interdependence create 'private structures of co-existence' which are fundamental for defining the very conditions of life (Lahire, 1995). In sum, in order to identify the objective circumstances surrounding the inherent subjectivity in female solutions for combining work and family life, we must look at relations of interdependence, on the assumption that they make a decisive contribution to defining what capital or resource can be mobilised by individual strategies.

Using an interpretative framework which seeks to account for 'social relational constraints' on the incorporation and activation of structural properties, I adopt an approach very close to the dispositional approach suggested and developed by Lahire (1995). By identifying dispositions which have been 'activated' or 'inhibited' in the commitments involved in devising strategies for reconciling family and work I am able to understand how subjects manage the tensions between the dynamics of action, and two forms of tension in particular: those between the norms implicit in gender roles and personal interests; and those between the subject's conception of him- or herself and the interpersonal dynamics of domination.

The first type of tension is observed at the 'paradigmatic' level, when subjects distance themselves from the rules, with a view to preserving their independence, achieving their individual objectives or even instrumentalising the rules themselves (Mouzelis, 2000). In fact, rules are quite commonly negotiated, as evidenced by the many ways in which gender norms are readjusted in family interaction (Björnberg, 2004). The second type of tension reflects the very plasticity of human behaviour. As far as work-family articulation is concerned, I argue that choices are made not according to a give-and-take model, but in line with the opportunities which individuals identify in each situation and their ability to deal with it. On the one hand, in certain occupational or family contexts individuals are permanently subject to decisions and assessment by others, in the same way that they learn to dominate and compete to the extent that they witness the ways in which authority - or even abuse of power - is exerted in primordial structures of interdependence like school and family. On the other hand, individuals are always left with a degree of freedom to modify the way external constraints or dispositions influence their action.

In the analysis of gender inequalities underlying work-family articulation it is crucial to differentiate the woman's attitudes concerning the division of labour and her attitudes towards the male career. Four kinds of female strategies for reconciling family and work can be identified. In the family-oriented strategy, the woman's attitude towards the division of labour is primarily ruled by gender norms and priority is given to the male career. The maximising strategy reveals a dissonance between equalitarian principles and normative gender prescriptions: the woman has a predisposition to negotiate domestic work in order to maximise her stakes in both career and family, yet she gives precedence to the male career. In the conflict management strategy, the woman seeks to manage the conflict within the couple concerning the division of domestic work since her career stake is, at least, as strong as that of her partner. Finally, in the shared balancing strategy, the woman combines work and family demands within a conjugal context where both partners develop strategies for achieving equality. 


\section{Data and Methodology}

The heuristic potential of the analytical framework set out here will be illustrated through two empirical examples drawn from a qualitative study on 'Marriage and Inequality' (Rosa, 2013). I have selected these cases since they particularly illustrate how negotiation between partners is crucial to define work-family articulation strategies, and they clearly show how gendered norms persist despite the different strategies. As part of this study, in-depth interviews were conducted with 27 university-educated Portuguese women with demanding jobs in terms of time and qualifications, living jointly with a spouse and at least one school-age child (aged between six and 16). ${ }^{2}$ The strategy of interviewing women was adopted because it is mostly women who experience work-life conflict. The aim was to examine situations where there was a tendency for their occupational interests to collide with the interests of their male partners. Since the major research focus was female work-life experiences, the interviewees' biographies were analysed according to the key themes emerging from the data, namely their choices with regard to their family life, their career aspirations and the way they negotiate them with their male partners. The criteria governing the choice of interviewees were therefore educational attainment, occupation, conjugal and parental situation, and age.

The interviews lasted between three-and-a-half and four-and-a-half hours because the aim was to thoroughly address the work-life path of the interviewees and cover a range of topics, such as socialising practices during childhood and adolescence, work and career, work and family life, childcare, domestic tasks and conjugal negotiation. All the interviewees expressed their willingness to be interviewed. In fact, they were flattered to be asked about their own work-life experiences. The interviews attempted to get the interviewees to talk about their 'choices' regarding family and working life, their career aspirations and especially their solutions for reconciling the demands of work and career on the one hand, and the responsibilities of a family life with children on the other. A qualitative approach was effectively seen to be better suited to an analysis of how things are interiorised, activated or rejected and how gender norms governing the division of labour are reformulated. With ages ranging from 30 to 54, all the women interviewed were in their first marriage, having started their conjugal lives at around 20 years of age, and most of them between 25 and 29. Over half of them had two children, the rest being divided almost equally between those with just one child and those with three or four. Nearly all the interviewees had finished their degrees at the start of their conjugal lives.

\section{Work-Family Articulation Dynamics and Social Distance between Spouses: Two Examples}

Among all the interviewees, I found nine women with the family-oriented strategy, six women with the maximising strategy, eight women with the conflict management strategy and four women with the shared balancing strategy. The in-depth analysis of the empirical examples in this section enabled us to observe two different female strategies for reconciling family and work - maximising and conflict management - and their implications for social distance between spouses. Three main reasons governed the choice of the following examples. First, they both show that the social distance between 
women and their partners can change over the course of the conjugal life, and this change cannot be dissociated from the ways in which family obligations are combined with the demands of careers. Second, they both reveal very clearly the role of inter-subjectivity - that is to say, relational conditions - in female attitudes and choices regarding careers. Finally, they both show the inherent complexity in drawing up strategies for reconciling family and work, clearly suggesting that the relationship between gender norms and female choices - in other words, between structure and action - has to be the object of constant empirical scrutiny.

\section{Subordinating to the Man and Searching for Maximal Balance between Career and Family}

Júlia met José when she was 22. Like her, José is the child of small shopkeepers. They have been married for 21 years, and have two children, aged 16 and 20. At 52, Júlia has a degree in Economics, and today holds a position as head of division in the office of a Secretary of State, but states her dissatisfaction with her professional status, admitting that she moderated her early career ambitions. José, who is a civil engineer, and also a civil servant, has a position as a board director, the status of his position matching the ambitions he had for his career. Being six years older than Júlia, he already held a post as head of division when he married Júlia, who at the time was a senior executive officer.

The social mobility that Júlia mapped out for herself was not due to her family of orientation. Júlia's father always discouraged her from pursuing her studies. From childhood and adolescence she recalls the isolation she felt from lack of support - 'I had noone to talk to about school', but also the 'shame' of a social background revealed to her schoolmates by what she wore, in high schools attended by children from better-off backgrounds. But she does emphasise the importance of the regular visits she made to her sister's godmother, whose lifestyle and affluence made a strong impression on her. This regular contact with a social milieu so different from her own accentuated her feelings of 'shame' and 'triggered' her ambition for an affluent life, which was the basis for her aspirations for upward social mobility. The path she marked out for herself was thus initially based on a strategy of upward social mobility which led her to commit to higher education, with a view to achieving a standard of living which would enable her to satisfy the desires of someone who 'had never [had] anything she liked'. But that strategy was also devised with the aim of freeing herself from the paternal yoke:

I always had to be helping my parents and, as my father was very repressive - the household was very violent! - he wanted me to work and be ready to help. I didn't even have time to play! I did my homework when I got home and that was it, I had to help out, because he made me.

While she was still in secondary school, she went against her father's wishes by pursuing her studies, seizing the opportunity for independence provided by the income from 'lessons' she gave to classmates. She confesses to being 'a very materialistic woman' who, disregarding her vocation completely - 'I didn't really know what I wanted to do' - chose the undergraduate course in Economics, with the aim of eventually getting a very good salary. She started with a job in the office of a Ministry, after she had finished her 
first year. She recalls how hard it was to go to work while still doing her first year: 'when I took that job I worked all day, I was in class until midnight, I often studied until three in the morning'. But starting to work meant a profound change in the person she was - 'I had no friends, male or female' - because it opened up the outside world to her.

There is a strictly rational orientation underlying Júlia's will to ascend to a higher social echelon. This acknowledged rationalisation of her decision extended even to the choice of her partner. Júlia admits she prevented her emotions from interfering in the choice of her partner: 'I am a very emotional woman, but I'm also extremely rational, and here the rational came out on top.' Her husband, José, was therefore 'chosen' according to a 'model', having been one among 'many' suitors. He was the one who 'scored the highest', even though he was not one of her 'grand passions'. A decisive 'criterion' in mate selection was educational resources: 'I couldn't see myself having a degree and my husband having I don't know what.' Nevertheless, her plans for upward social mobility had not been devised in an emotional vacuum, since Júlia sought in her conjugal relationship the support and equilibrium which she had not found in her family of orientation:

I didn't have much time to think, I had no points of reference. So the only point of reference was this: it was either him or my father, wasn't it? And, for me, he was always going to be better than my father!

In the course of her conjugal life, however, Júlia gradually became disillusioned, and admits that today her relationship with José is strained. An increasing absence of affinities, lack of communication and progressively greater conflict meant that the conjugal dynamic came to be based on Júlia's subordination to her husband's decisions - 'he didn't like it at all if I came home late from work, so he didn't want me to have longer working hours' - and on an unequal distribution of household tasks. While José does help with some tasks, the fact is that most of the household responsibilities fall to Júlia, namely all the logistics of the household and dealing with the family's property assets.

This impaired relational framework, visibly marked by male domination, was thus a decisive factor in Júlia's refusal to accept successive offers of board-level jobs. On the one hand, her career aspirations were negatively affected by a family situation which became increasingly demanding, with even a maid not being sufficient for her to extend her working day and take on director-level responsibilities. On the other hand, this domestic overload was aggravated by José's resistance to her commitment to her career and further progression in it. Having no family support network at all - 'I had no-one with whom I could leave my kids' - she was forced to take on the duty of making herself more available for her family. Júlia did not, however, question José's acceptance of a Director-level post, which not only increased her husband's working day from eight to 10 hours, but also increased the difference between their salaries, in favour of the man. Underlying Júlia's subordination is her own attitude towards family life, which is ruled by gender norms. Her gender-structured attitude results in a feeling of affective duty with regard to the family and contradicts her inclination to autonomy through paid work. This case illustrates how power between partners acts through gendered norms: Júlia shows a higher degree of 'distancing from rules' (Mouzelis, 2000: 748) in professional life than in family life. Her upward social mobility is finally limited because she reproduces the 
gender roles in the family. Now that childcare demands are no longer an issue, she 'regrets' the decision she took in career terms:

They invited me to be head of division, I didn't accept because of my family life, my children were still very small ... I was invited to join the office of the Secretary of State, but I turned it down. I was invited for Under Director-General in various organisations and I refused ... because of family life! ... Today I don't feel fulfilled, far from it! If I'd known what it is to get married and have children, I'd be on my own today ... I'd never have got married, because it cut off most of my freedom, so to speak. I feel very, very deprived!

Júlia's words help to explain the dynamic nature of homogamy, and show that the relative social inequality between her and her husband increased as a result of a set of decisions based on a 'primary mother gendered moral rationality' (Duncan et al., 2003) which led to constant refusal to accept positions which would today give her socio-professional standing equal to that of her husband, rather than on an individualised rationality. Júlia's work-life choices in fact reveal not only how she articulated normative expectations vis-a-vis family life and her own career aspirations, but also and above all how she managed her own individual freedom in family situations involving dynamics of domination/subordination.

This work-life biography shows the complexity of relational processes underlying action - a complexity which synthetic indicators of homogamy cannot capture. Júlia's experiences during her childhood and adolescence underline the importance of contacts with other social milieus and the incorporation of contradictory aspirations into strategies for reproducing the family. Júlia's exposure to frameworks of socialisation outside the family nucleus allowed her to set out a personal plan for upward social mobility and thus to resist the suppression of her individuality in a father-dominated family context. This individual upward mobility plan involved the rationalisation, in the economic sense of the word, in mate selection, so as to avoid her emotions creating obstacles to her ascetic dispositions, which were of fundamental importance for the realisation of her upward plan. Once she had become part of a structure of interdependence such as her current family situation, which encouraged both pre-given non-negotiable gender roles and male dominance, Júlia's ascetic inclination proved to be weaker than she anticipated and susceptible to relations of interdependence. Júlia's employment and career decisions vis-a-vis family responsibilities are based on her inability to negotiate her moral understandings with her partner and countering the obstacles he placed in her way: José is opposed to her making any greater commitment to her career, either in the shape of longer hours, or by accepting positions of greater responsibility and self-sacrifice. In sum, underlying Júlia's inability to negotiate is a feeling of affective obligation, which has led her to give up her career aspirations and towards greater dedication to the family.

\section{Taking the Lead in the Conjugal Relationship and Managing the Work-Family Conflict}

Lurdes has been married and living for 10 years with Sebastião, with whom she has a six-year-old son. They both come from low qualified backgrounds, have university degrees and have marked out a path of upward social mobility. Sebastião, who is a 
geographer and civil servant eight years younger than her, had not yet started university when they met. Lurdes was just finishing her degree in Psychology, and she was the only one working when they decided to get married. At 41 years of age, Lurdes currently combines her academic skills with being self-employed, dividing her time between consultations, training and the design of pedagogical-type products. As we shall see below, despite the fact that Sebastião is also committed to higher education, the relative sociooccupational difference between them - which has always been reflected in unequal statuses and incomes - increased over the course of their conjugal life. While initially reflecting the fact that she was older than Sebastião, that difference would end up increasing as a result of Lurdes' strong commitment to her career. However, her work commitment was only possible because of the nature of the interdependence which always characterises their family life.

Lurdes was three years old when she moved with her parents from a village in the country to Lisbon. The short period of childhood in the village where she was born nonetheless had enough of an impact on her that she retained strong emotional ties with her paternal grandmother, whose unyielding dispositions of a female leader Lurdes incorporated:

It was my grandmother who was boss, even though my grandfather put on a big show ... Thinking aloud, if I have to choose a role model, out of my mother, my maternal grandmother or my paternal grandmother: it's my paternal grandmother, without a doubt!

In turn, the autonomy dispositions which Lurdes had incorporated through her relationship with her grandmother contrast with Lurdes' mother's 'controlling' attitude. Her mother is portrayed as someone who 'gives but expects something in return'. Lurdes only felt free from her 'control' when she finished High School: 'my status [in the family] changed when I went to university'. At the university there was a new circle of friends, which included a 'best friend', Sebastião's first cousin. It was through her that she met him. Sebastião was only 17 when they started going out together, but Lurdes saw in him someone with whom she could communicate and, above all, someone who met her demands: 'I thought he was what I needed.' Hence her preference for a man whom she felt she could strongly influence, even encouraging him to pursue and conclude a higher education course, is a first indicator of the matriarchal dynamic she had experienced in her paternal grandmother's home.

In fact, Sebastião's career trajectory reflects the fact that Lurdes has always occupied a position of guidance and leadership in the conjugal relationship itself. Her ability to guide and influence her partner was decisive in helping him mark out a path of upward social mobility. Lurdes' influence was crucial for the professional choice of Sebastião, who today has a job 'far more in line with his creativity'. But, in turn, she also depends on Sebastião's 'fundamental work support', since it is he who gives the IT support required for the design of her pedagogical-type products. She had even invited him to work full-time on her entrepreneurial project, but he declined, because he was afraid of Lurdes' 'temperament' as a 'boss'. As far as her career is concerned, Lurdes' propensity for leading is reflected in an 'inability to work for someone else'. But this inability makes her proud of a career path which is the outcome of her ability to be independent: 'I was always the one, it was always really me who carved out my own career path.' 
Lurdes' career aims were set out during her professional training. She did an internship in a state hospital because she wanted to gain professional experience with children with a disability. Having concluded this period of training, Lurdes went on to a further internship abroad and when she came back, at the age of 25 , she started to work in her own private practice. From that time on she devoted herself completely to her career, until at the age of 32 she was diagnosed with a very debilitating illness. The illness was a turning point in her career. The chronic physical pain obliged her to interrupt her work path. She actually was out of work for a year. But Lurdes gradually learned to 'live with the illness' and decided to reconstruct her career path as self-employed: she developed a business model which would allow her to work from home and replace 'routine' with 'creative' work solutions in the same field. When she unexpectedly became pregnant with the couple's only child, Lurdes had to reorganise her working life. As a result of her illness, she drew up a temporary list of priorities and gave up trying to combine a fulltime demanding job and motherhood because she believed a child 'needs a lot of attention':

There are lots of things that drive me, and I can't commit myself to a lot of things at the same time ... A child ... demands a lot! I can't do the two things at the same time, because what I'm doing is also an act of creation.

Six months after her child was born, she restarted working, but not on a full-time basis. Only after her child had reached four years of age did she devote herself full-time to her work. Lurdes has ruled out having a second child because she fears the potential conflict resulting from the incompatible pressures of individual interests and motherhood. She actually claims that she has 'many interests which speak louder' than motherhood, clearly referring to interests related to her work and career:

I can't see the motherly instinct increasing with age! On the contrary! I think I want to do other things ... Maybe these interests seem a bit selfish. I personally don't think so. But you hear a lot of people say that, you know.

Lurdes' fear of a work-family conflict is also greatly increased by an uneven division of household work. Except for administrative matters Lurdes has found Sebastião almost totally unwilling to help with household work. She resorts to humour when she confesses she has 'given up' trying to negotiate the housework:

There's no sharing: the boy does nothing! So of course, if the boy does nothing, then I have to do it all! ... When he gets home, I've already done the work and am lying on the sofa with a pain in my back ... There's no conflict, because I've already given up.

It should be noted that the actual absence of conjugal negotiation regarding housework can be circumvented because the couple have a strong family support network. Lurdes' parents in particular are always available to do the whole family's laundry and ironing, cook the two main meals of the day or stay with the child when necessary. This support frees her up from some of the heavier and more routine household tasks. It is also Lurdes who is mainly responsible for childcare. Since she is working from home, it is 
mainly Lurdes whom the child 'asks for' on a day-to-day basis. Parenthood roles were always well defined and distributed between partners. When the child was a baby, she recalls, 'the fatherly thing to do was to bath the baby!', while today paternity is mostly practised in playing with their son.

This second example too shows the limitations of the classic homogamy indicator. The initial difference arising from the age disparity between Lurdes and Sebastião when they met gave way to shared mobility trajectories as a result of educational attainment by both of them. But while these attainments brought the man socially closer to the woman, that approximation did not eliminate the professional status and income differences between spouses. In order for those differences to persist, a decisive factor was a structure of family interdependence which lessened the effects of the domestic division of labour. The division of labour could otherwise have been a source of tension between this 'primarily worker' mother - who gives primacy to paid work as separate to her identity as mother (Duncan et al., 2003) - and her partner, but Lurdes has been able to manage the tensions between expectations of her role as a mother and her career interests thanks to her parents' intervention in helping with domestic work, on the one hand, and her husband's direct support with her professional activity on the other. In sum, this set of relations of interdependence enabled Lurdes to achieve her complete independence by developing an entrepreneurial project, which would otherwise have been thwarted both by the limitations arising from adversity and a desire to be close to her son. For someone whose relational dispositions associated with motherhood are so strongly incorporated vis-a-vis the leadership dispositions inherited from her paternal grandmother, work-family articulation might have proved to be particularly difficult in another family context.

\section{Discussion and Conclusion}

My main point in this article is to question an approach to homogamy which is restricted to the moment when a spouse is chosen. I argue that this static approach is too narrow in the study of contemporary capitalist societies, in which the dynamics of the division of labour, both professional and domestic, are becoming more complex. In societal contexts such as Portugal where the dual earner model is now predominant, the social distance between the spouses is not necessarily 'crystallised' at the moment a couple is formed and the (re)production of gendered social inequalities can be at the heart of the marital dynamics. I therefore put forward a dynamic analysis of homogamy.

In the empirical examples analysed here there were not significant differences between spouses in terms of occupational status and educational resources when the couple was formed, yet the closeness of all these structural properties fails to explain the trajectories of both partners. The social proximity between Júlia and her partner when they came together as a couple was partially undone as she gave increasing precedence to family demands. In turn, Lurdes' commitment to her career, even when she was faced with the adversity of a debilitating illness, brought about a relative difference in her favour in their occupational status. Both cases illustrate that social homogamy is a dynamic process and social (in)equality between partners depends on the gendered interdependency which characterises these homogamic couples. 
My second argument has to do with the conceptualisation of female decisions regarding work-family articulation. Standing back from both the more subjectivist and rationalist approaches and the more structuralist and mechanistic, I posit that women's decisions in order to combine job demands and family roles result from their strategies for reconciling family and work. I argue that female strategies are both rational in the light of the relational and structural constraints present in any given situation and affected by possible tensions between individual career interests, normative expectations regarding family roles and the perception of oneself as subject. As far as work-family articulation is concerned, female choices cannot be analysed outside the conjugal and family context of which they are a part. In the first work-life biography analysed, it was actually observed that a lack of communication between partners and hence a non-negotiable establishment of pre-given gender roles within the couple progressively inhibited Júlia from developing the asceticism required for her to grasp the opportunities for progress in her career. Júlia's professional qualities - work commitment, 'co-ordination' and 'leadership' - which are recognised at her workplace, derive from her dispositions towards social mobility which she incorporated in contexts of socialisation other than her family of orientation. But the activation of those dispositions is now impaired by a constraining conjugal framework, with its underlying logic of male domination, and by the lack of a family support network which would relieve Júlia of the excessive burden of household demands. In the second case analysed, Lurdes did not give up on her professional ambitions, even after being diagnosed with a debilitating illness. She was able to rely on a strong family support network, which itself largely helped to ease the pressure that the physical limitations caused by her disease had brought to work-family articulation, as well as on her husband's support on re-orienting her career path.

Finally, the empirical examples outlined here demonstrate actors' ability both to distance themselves from gender rules, and somehow to monitor the ongoing interactive frameworks in which their actions take place, based on their knowledge of their own reactions. Thus Júlia always sought to map out a path of upward social mobility by incorporating aspirations which contradicted family heritage social reproduction strategies. Lurdes, on the other hand, clearly sought to build a family interdependency structure which fits her tendency to lead and guide those around her. However, these work-life biographies also show that women's freedom of choice does not go beyond the limitations defined by the constraints of each situation. In fact, women are able to distance themselves from gender roles even when they face the pressures of job demands and family roles, but their freedom of choice is actually compromised when they experience the lack of a family support network. It suggests that even in a country like Portugal, known for its strong family support tradition, the role of the state is crucial to mitigate the inequalities which result from gender norms. By way of illustration, gender inequality seems to be challenged since Portuguese fathers' leave periods have become longer. As a recent study has pointed out, 'predominant patterns [of men on leave alone] reveal fathers who take on new responsibilities rather than delegate care and housework' (Wall, 2014: 208).

\section{Acknowledgements}

I would like to thank Catarina Lorga for reading the earlier versions of the article and for providing her helpful comments. I would also like to thank Karin Wall and the anonymous reviewers for their very useful comments. 


\section{Funding}

The Portuguese work-life interviews were carried out in the scope of the research project 'Marriage and Inequality' granted by Portuguese Foundation for Science and Technology/Portuguese Board for Science, Technology and Higher Education.

\section{Notes}

1. It should be noted that, unlike other European countries, working part-time is rarely an option for the majority of Portuguese working mothers. This is not only explained by the considerable increase in standard of living which comes with two full-time incomes, but also by a strong female work ethic which has its roots in the 1960s, when Portuguese men emigrated or went to colonial war (1961-1974) and women had to find a job (Rosa et al., 2015).

2. This qualitative study is a follow-up of a larger study on married women with children, carried out between 1997 and 2005. One of the aims of this former study was to create an overview of homogamic patterns in Portugal (Rosa, 2005). A further in-depth study, 'Marriage and Inequality', was carried out in order to explore the role of homogamic marriage on gender differentiation via the functioning of marital life.

\section{References}

Becker G (1981) A Treatise on the Family. Cambridge, MA: Harvard University Press.

Björnberg U (2004) Making agreements and managing conflicts: Swedish dual-earner couples in theory and practice. Current Sociology 52(1): 33-52.

Bourdieu P (1972) Les stratégies matrimoniales dans le système de reproduction. Annales. Économies, Sociétés, Civilisations 27(4): 1105-1127.

Bourdieu P (1987) Choses dites. Paris: Minuit.

Bozon M and Héran F (2006) La Formation du couple. Paris: La Découverte.

Buffier-Morel M (2007) L'Emploi du Temps au Féminin. Entre Liberté et Égalité. Paris: L'Harmattan. Crompton R (2006) Employment and the Family. Cambridge: Cambridge University Press.

Delphy C and Leonard D (1992) Familiar Exploitation. Cambridge: Polity.

Dubet F (1994) Sociologie de l'expérience. Paris: Seuil.

Duncan S, Edwards R, Reynolds T, et al. (2003) Motherhood, paid work and partnering: Values and theories. Work, Employment \& Society 17(2): 309-330.

Finch J and Mason J (1993) Negotiating Family Responsibilities. London: Routledge.

Girard A (1981 [1964]) Le Choix du conjoint. Paris: PUF.

Guerreiro MD and Pereira I (2007) Women's occupational patterns and work-family arrangements: Do national and organisational policies matter? In: Crompton R, Lewis S and Lyonette C (eds) Women, Men, Work and Family in Europe. Hampshire: Palgrave Macmillan, 190-209.

Hakim C (2000) Work-Lifestyle Choices in the 21st Century: Preference Theory. Oxford: Oxford University Press.

Junter-Loiseau A (1999) La notion de conciliation professionnelle et familiale. Les Cahiers du Genre 24: 73-98.

Lahire B (1995) Tableaux de famille. Paris: Seuil/Gallimard.

Le Bihan-Youinou B and Martin C (2008) Les enjeux de la conciliation vie familiale-vie professionnelle en Europe. In: Le Bihan-Youinou B and Martin C (eds) Concilier vie familiale et vie professionnelle en Europe. Rennes: Presses de l'EHESP, 5-34.

McNay L (1992) Foucault and Feminism. Boston, MA: Northeastern University Press.

Moss P and Wall K (eds) (2007) International Review of Leave Policies and Related Research 2007. London: Department for Business, Enterprise and Regulatory Reform. 
Mouzelis N (2000) The subjectivist-objectivist divide: Against transcendence. Sociology 34(4): $741-762$.

Nicole-Drancourt C (1989) Stratégies professionnelles et organisation des familles. Revue Française de Sociologie 30(1): 57-80.

OECD (2014) Children in families by employment status. Available at: www.oecd.org/social/ family/database.

Rosa R (2005) A escolha do cônjuge. In: Wall K (ed.) Famílias em Portugal. Percursos, Interaç̧̃es, Redes Sociais. Lisbon: Imprensa de Ciências Sociais, 117-161.

Rosa R (2013) Casamento e Desigualdade. Uma Análise da Diferenciação Social no Casal. Lisbon: Imprensa de Ciências Sociais.

Rosa R, Lorga C and Lyonette C (2015) Marriage and gender inequality: Work-family arrangements of Portuguese and British highly qualified women. Community, Work \& Family. Epub ahead of print 11 June 2015. DOI: 10.1080/13668803.2015.1040738.

Silvera R, Nadja B and Donlevy-Gomes V (2004) Articuler vie professionnelle et vie personnelle. Paris: Racine.

Singly F (1997 [1987]) Fortune et infortune de la femme mariée. Paris: PUF.

Wall K (2007) Leave policy models and the articulation of work and family in Europe: A comparative perspective. In: Moss P and Wall K (eds) International Review of Leave Policies and Related Research 2007. London: Department for Business, Enterprise and Regulatory Reform, 25-43.

Wall K (2014) Fathers on leave alone: Does it make a difference to their lives? Fathering 12(2): $196-210$.

Wall K and Guerreiro MD (2005) A divisão familiar do trabalho. In: Wall K (ed.) Famílias em Portugal. Percursos, Interacções, Redes Sociais. Lisbon: Imprensa de Ciências Sociais, 303-362.

Rodrigo Rosa is a sociologist and a post-doctoral research fellow at the Institute of Social Sciences of the University of Lisbon (ICS-UL). He holds a PhD in Sociology from the University Institute of Lisbon (ISCTE-IUL). He is an assistant lecturer at Autónoma University (UAL). He has been undertaking research in the areas of gender and family, work-family conflict and family policies in Europe. He has been over the last years carrying out a cross-national research on work-family articulation, family policy and gender equality in three European countries - Portugal, Sweden and France.

Date submitted November 2014

Date accepted March 2016 